\title{
A comparative study of the learning outcomes and students' satisfaction from problem-based learning and lecture-based learning in obstetrics and gynaecology
}

\author{
Valsa Chathampadathil Augusthy*
}

Department of Obstetrics \& Gynaecology, Pushpagiri Medical College Hospital, Thiruvalla, Kerala, India

Received: 03 April 2016

Accepted: 13 April 2016

\author{
*Correspondence: \\ Dr. Valsa Chathampadathil Augusthy, \\ E-mail: drvalsa777@gmail.com
}

Copyright: ( ) the author(s), publisher and licensee Medip Academy. This is an open-access article distributed under the terms of the Creative Commons Attribution Non-Commercial License, which permits unrestricted non-commercial use, distribution, and reproduction in any medium, provided the original work is properly cited.

\begin{abstract}
Background: Problem-based learning (PBL) has been endorsed by bodies such as the World Health Organization and Medical Council of India as a solution to both the ills of medical education and new challenges such as clinical governance. This empirical study was undertaken to assess and compare the learning outcomes at various levels of cognitive domain like recall, analysis and comprehension, and application in Obstetrics and Gynaecology (OBG) course by implementing lecture-based learning (LBL) and problem-based learning methods. It also aimed to assess the students' satisfaction and opinion about LBL and PBL methods.

Methods: Three batches of final year MBBS students of Pushpagiri Medical College Hospital, Thiruvalla, posted in the department of Obstetrics and Gynaecology during the study period of 6 months were conveniently selected for the study. Each batch of 14 students was divided into 2 groups randomly and two topics of OBG were taught using LBL and PBL methods for both the groups. The peer reviewed tests consisted of ten questions each for both the topics of OBG addressing the various levels of cognitive domain were administered before and after the sessions. After each session the students were also asked to fill the Satisfaction Questionnaire anonymously in order to assess students' opinions about PBL and LBL methods.

Results: The results of the study proved that in comparison to LBL, the PBL method produces better outcomes of recall, analytical and critical thinking in addition to problem solving skills. PBL had been found to be a more effective form of learning method with a greater degree of learning satisfaction and motivation as compared to the conventional LBL method.

Conclusions: PBL method is a more effective instructional tool to foster critical thinking and problem solving skills among medical students as compared to the traditional LBL method and students are more satisfied with the PBL method in Obstetrics and Gynaecology.
\end{abstract}

Keywords: Problem-based learning, Lecture-based learning, Hypertension, Diabetes

\section{INTRODUCTION}

The undergraduate medical education scene requires ongoing improvement to keep rhythm with the changing demands of the 21 st century, especially in medical practice. The older medical schools are reviewing their curriculum while new schools are developing their programs following current trends in medical education, particularly problem-based learning (PBL) and integrated curricula. While medical schools are moving from traditional lecture-based learning (LBL) to PBL curricula it must be kept in mind that before shifting from one curriculum to another, there is a need to conduct a series of studies in their own educational environment to have an idea of the selection of the appropriate tool for teaching and learning. Keeping in view of all these facts, this empirical study was conducted to compare and assess the learning outcomes in Obstetrics and Gynaecology 
(OBG) course by implementing conventional lecturebased learning and problem-based learning methods.

\section{Review of literature}

Traditionally, medical students have been taught basic science and introductory clinical material in the conventional lecture format. It has long been assumed that such lectures impart the greatest amount of information in the shortest period of time, forming the framework for future clinical learning. ${ }^{1}$ However, it is now understood that little of what is taught in a purely lecture format is actually retained by the students. It is estimated that students' attention diminishes after 10 minutes of passive listening, limiting what is learned. ${ }^{2}$ Additionally, lectures do little to challenge and stimulate the students to problem solve, a skill that is necessary for their clinical years as well as their medical careers. ${ }^{3}$

The idea of problem-based learning came from Case Western Reserve University in the mid-1950s. ${ }^{4}$ It was spread due to the work of Harold Barrows, a professor at McMaster University, Canada, over the late 1960s. ${ }^{5}$ In 1974, The Maastricht University became the first in Europe to integrate PBL into course work. At the turn of the 20th century, nearly 150 medical schools worldwide had integrated problem-based learning into their curricula. $^{6}$ The Medical Council of India encourages integrated teaching using the PBL approach. ${ }^{7}$

Problem based learning is described throughout the literature as an inquiry based approach to learning that is student centered and provides the means for gaining problem solving and lifelong learning skills. ${ }^{8-10} \mathrm{PBL}$ is geared to facilitate knowledge retention and application while fostering the skills desired in physicians, such as clinical reasoning, critical thinking and self-directed learning. ${ }^{11}$ The PBL approach has been found to improve physician competency in the social and cognitive domains. $^{12}$ In the PBL session the teacher's role is to facilitate collaborative knowledge construction. PBL student groups are characterized by 5 to 9 individuals attempt to resolve a real-life clinical problem by using their existing knowledge to generate hypotheses and then actively finding the cross-disciplinary knowledge they need to fully understand the problem. PBL triggers/problems/tasks are utilized to stimulate the student's interest in resolving the problem scenarios presented to them. PBL delivery should be conducted in two sessions. In the introductory session the group members will be advised by the facilitator to choose among them the chairperson of the group for the session. The chairperson is responsible for agreeing group processes, introducing the case to the group, inviting participation and ensuring all members are contributing. $\mathrm{He} / \mathrm{she}$ also ensures that all areas are covered and oversee timekeeping. The group after better comprehension of the problem should visualize for facts and ideas in the trigger. The brainstorming session should be followed after creating certain facts for the research to achieve the best conclusion. After the completion of the session the facilitator must address the group about their outcome with compliments and encouraging remarks so as to infuse the habit of critical thinking and problem solving. After completing first session, students are responsible to do independent and self-directed learning. Students gather information and ideas from reliable sources. Use the full range of useful resources available; organize responses to each learning outcome, making summarized notes. They would be allowed to reassemble and discus their finding after a week in second session. After the students are allowed to go for self- directed learning using academic resources they are allowed to meet again for closing session of PBL pedagogy. The students shall now be equipped with newly acquired knowledge; the group reconvenes to discuss the case. The discussion includes an explanation of the central concepts and mechanisms, analysis of the material and evaluation of its validity and importance. The facilitator may help students where they lack information, but should be cautious in moving their team to their view point. After the discussion has been done the chairman should summarize the data and cross check if the learning needs have been addressed effectively. The chairman may also consult among the group and once satisfied with the academic aspects should announce for the closure of the session. After the student chairman announces the closure of the session the facilitator should take charge and summarize the events in a constructive manner and he/she should evaluate the session based on the learning needs accomplished. Students should also be asked to give viewpoints in respect of their own performance and that of their peers. ${ }^{13}$

\section{Objectives of the study}

The major objectives of this study are to assess and compare the learning outcomes at various levels of cognitive domain like recall, analysis and comprehension, and application in Obstetrics and Gynaecology course by implementing LBL and PBL methods. It also aims to assess the students' satisfaction and opinion about LBL and PBL methods.

\section{METHODS}

After due clearance from the Institutional Ethics Committee and written consent from the students, this quasi experimental study was conducted in the department of Obstetrics and Gynaecology, Pushpagiri Medical College Hospital, Thiruvalla, from $1^{\text {st }}$ July to 31st December 2015. Each batch of 14 final year MBBS students posted in the OBG department was divided into 2 groups randomly and two topics of OBG (Hypertension in Pregnancy and Diabetes in Pregnancy) which were not taught in the theory classes or at the patient's bedside were chosen to compare the learning outcomes in LBL and PBL methods. 
For the first group of students (A), the Hypertension in Pregnancy (topic a) was taught as lecture by the researcher in the OBG ward. The second group of students (B) learned the same topic (a) in clinics with PBL method. After two weeks, the second topic Diabetes in Pregnancy (b) was presented by PBL method to the first group (A), and the same topic (b) was taught as lecture for the second group (B). Both lectures were presented by the same lecturer. The same pattern was repeated for the three batches of 14 students each posted in the department of Obstetrics and Gynaecology during the study period.

A peer reviewed test consisted of ten questions for each topic addressing the various levels of knowledge domain like recall, analysis and comprehension, and application was administered before and after the sessions. The validity and reliability of the individual questions were assessed using Cronbach's alpha test. Evaluation of the answer sheets were done using a key prepared during validation of the question paper. The marks of the pre-test and post-test were charted depending on the type of questions into three groups based on the level of knowledge as recall, analysis and comprehension, and application. The marks were then analysed statistically to observe the statistical significance of the scores obtained for PBL and LBL. Differences were considered to be statistically significant if the $\mathrm{P}$ value was less than 0.05 .

After each session the students were asked to fill the Students' Satisfaction Questionnaire anonymously. The Students' Satisfaction Questionnaire assessed and compared students' opinions about PBL and LBL in the fields of gaining clinical reasoning skills, facilitation of problem solving skills, facilitation of communication skills, facilitation of self-directed learning, gaining robust and retrievable knowledge, usefulness for answering examinations, facilitation of integration of basic and clinical science knowledge, increasing intrinsic motivation of students, the attractiveness of teaching method, and the overall satisfaction of the teaching method. Responses of the Students' Satisfaction Questionnaire were marked on a 5-point Likert scale, ranging from 1 (strongly disagree) to 5 (strongly agree). The reliability of Students' Satisfaction Questionnaire had a Cronbach's alpha of $87 \%$. Data were analyzed using SPSS and the level of significance was set at $p$ $<0.05$ for all tests.

\section{RESULTS}

There were 34 females $(80.95 \%)$ and 8 males $(19.05 \%)$ among the 42 final year MBBS students enrolled in this study. No statistical significance was found between the groups of students in terms of age, grade, marital status and socio-economic status $(\mathrm{p}>0.05)$. There was no significant difference in the outcome with different topics.
The following graph exhibits pre-test results and the comparative post test results of the outcomes of lecturebased learning and problem-based learning.

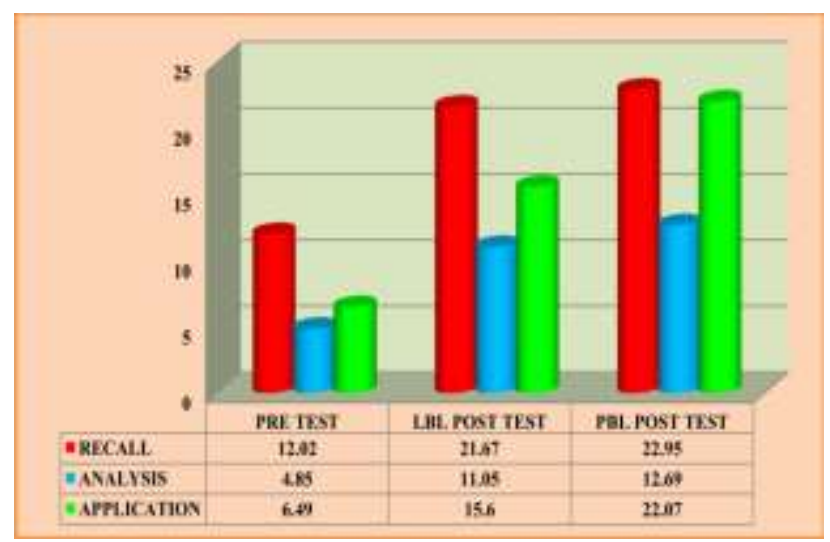

Figure 1: Comparative results of the outcomes of lecture-based learning and problem-based learning.

Table 1: Students' opinion about lecture-based learning method.

\begin{tabular}{|c|c|c|c|c|c|}
\hline & Items & Mean & SD & $\mathrm{T}$ & p-value \\
\hline 1 & $\begin{array}{l}\text { Gaining clinical } \\
\text { reasoning skills }\end{array}$ & 2.667 & 0.874 & 19.769 & $0.000 *$ \\
\hline 2 & $\begin{array}{l}\text { Facilitation of } \\
\text { problem solving } \\
\text { skills }\end{array}$ & 2.500 & 0.917 & 17.662 & $0.000 *$ \\
\hline 3 & $\begin{array}{l}\text { Facilitation of } \\
\text { communication } \\
\text { skills }\end{array}$ & 2.167 & 0.762 & 18.417 & $0.000 *$ \\
\hline 4 & $\begin{array}{l}\text { Facilitation of } \\
\text { self-directed } \\
\text { learning }\end{array}$ & 2.333 & 1.028 & 14.709 & $0.000 *$ \\
\hline 5 & $\begin{array}{l}\text { Gaining robust, } \\
\text { retrievable } \\
\text { knowledge }\end{array}$ & 3.000 & 1.104 & 17.606 & $0.000 *$ \\
\hline 6 & $\begin{array}{l}\text { Gaining basic } \\
\text { science } \\
\text { knowledge }\end{array}$ & 3.119 & 1.564 & 12.917 & $0.000 *$ \\
\hline 7 & $\begin{array}{l}\text { Facilitation of } \\
\text { integration of } \\
\text { basic and clinical } \\
\text { science } \\
\text { knowledge }\end{array}$ & 2.762 & 1.031 & 17.354 & $0.000 *$ \\
\hline 8 & $\begin{array}{l}\text { Increasing } \\
\text { intrinsic } \\
\text { motivation of } \\
\text { student }\end{array}$ & 2.571 & 1.085 & 15.356 & $0.000^{*}$ \\
\hline 9 & $\begin{array}{l}\text { Facilitation of } \\
\text { development of } \\
\text { self-assessment } \\
\text { and peer } \\
\text { assessment skills }\end{array}$ & 2.548 & 1.017 & 16.235 & $0.000^{*}$ \\
\hline 10 & $\begin{array}{l}\text { Overall } \\
\text { effectiveness of } \\
\text { LBL }\end{array}$ & 2.857 & 1.159 & 15.066 & $0.000 *$ \\
\hline
\end{tabular}

*Statistically significant 
The highest level of students' agreements in LBL method (mean+/-SD) was related to "gaining robust and retrievable knowledge" compared to other items of gaining clinical reasoning skills, problem solving skills, communication skills, self-directed learning, basic science knowledge and the development of selfassessment and peer assessment skills.

Table 2: Students' opinion about problem-based learning method.

\begin{tabular}{|c|c|c|c|c|c|}
\hline & Items & Mean & SD & $\mathrm{T}$ & $\begin{array}{l}\text { p- } \\
\text { value }\end{array}$ \\
\hline 1 & $\begin{array}{l}\text { Gaining } \\
\text { clinical } \\
\text { reasoning skills }\end{array}$ & 4.333 & 0.612 & 45.922 & $0.000 *$ \\
\hline 2 & $\begin{array}{l}\text { Facilitation of } \\
\text { problem } \\
\text { solving skills }\end{array}$ & 4.214 & 0.606 & 45.047 & $0.000 *$ \\
\hline 3 & $\begin{array}{l}\text { Facilitation of } \\
\text { communication } \\
\text { skills }\end{array}$ & 4.176 & 0.652 & 42.588 & $0.000 *$ \\
\hline 4 & $\begin{array}{l}\text { Facilitation of } \\
\text { self-directed } \\
\text { learning }\end{array}$ & 4.119 & 0.861 & 30.999 & $0.000 *$ \\
\hline 5 & $\begin{array}{l}\text { Gaining robust, } \\
\text { retrievable } \\
\text { knowledge }\end{array}$ & 3.833 & 0.824 & 30.152 & $0.000 *$ \\
\hline 6 & $\begin{array}{l}\text { Gaining basic } \\
\text { science } \\
\text { knowledge }\end{array}$ & 3.905 & 0.759 & 33.341 & $0.000 *$ \\
\hline 7 & $\begin{array}{l}\text { Facilitation of } \\
\text { integration of } \\
\text { basic and } \\
\text { clinical science } \\
\text { knowledge }\end{array}$ & 3.929 & 0.808 & 31.499 & $0.000 *$ \\
\hline 8 & $\begin{array}{l}\text { Increasing } \\
\text { intrinsic } \\
\text { motivation of } \\
\text { student }\end{array}$ & 4.048 & 0.582 & 45.044 & $0.000 *$ \\
\hline 9 & $\begin{array}{l}\text { Facilitation of } \\
\text { development of } \\
\text { self-assessment } \\
\text { and peer } \\
\text { assessment } \\
\text { skills }\end{array}$ & 4.071 & 0.746 & 35.394 & $0.000 *$ \\
\hline 10 & $\begin{array}{l}\text { Overall } \\
\text { effectiveness of } \\
\text { PBL }\end{array}$ & 4.143 & 0.718 & 37.388 & $0.000^{*}$ \\
\hline
\end{tabular}

*Statistically significant

When looking at the students' opinion about PBL Method, the item with the highest level of students' agreements (mean+/-SD) related to "gaining clinical reasoning skills" followed by problem solving skills and communication skills. The mean scores of all the items in comparison with PBL and LBL, in the opinion of the students, indicate that PBL is more effective than LBL in OBG.
The following graph depicts the comparative scores of the students' opinion about the satisfaction level of LBL method and PBL method based on 10 parameters.

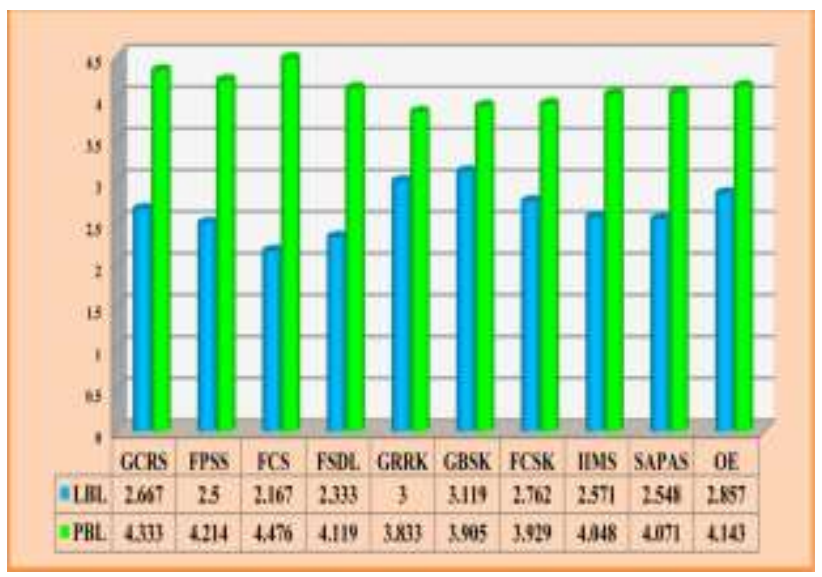

Figure 2: Comparative scores of students' satisfaction.

\section{Results of hypotheses tests}

Table 3: Learning outcomes of LBL and PBL in obstetrics and gynaecology.

\begin{tabular}{|lllll|}
\hline Method & Mean & SD & $\mathrm{t}$ & $\mathrm{p}$-value \\
\hline LBL & 16.10 & 6.346 & 28.485 & $<0.001$ \\
\hline PBL & 19.24 & 6.007 & 35.948 & $<0.001$ \\
\hline
\end{tabular}

There is statistically significant difference in the learning outcomes of LBL and PBL in Obstetrics and Gynaecology.

Table 4: Students satisfaction compared to LBL and PBL in obstetrics and gynaecology.

\begin{tabular}{|lllll|}
\hline Method & Mean & SD & t & p-value \\
\hline LBL & 2.65 & 1.098 & 49.501 & $<0.001$ \\
\hline PBL & 4.11 & 0.732 & 115.073 & $<0.001$ \\
\hline
\end{tabular}

There is statistically significant difference in the satisfaction level of the students while comparing the LBL and PBL methods in OBG. Compared to LBL, PBL method gives more satisfaction for the students as evidenced by the higher mean value of PBL method.

\section{DISCUSSION}

The present study which compared problem based learning method and the conventional lecture based learning method shows that PBL has a definite advantage in equipping the learner with factual recall, development of their analytical and critical thinking skills in addition to problem solving skills. This is in conformity with the study of Gibbon, which found that PBL can help the students to become more effective in identifying, seeking out and assimilating knowledge and it also helps to foster the development of their analytical and creative skills. ${ }^{14}$ 
Several studies have reported the improvement of other aspects of learning such as developing communication skills, autonomy, motivation development, and increasing the capacity of remembering the information as advantages of PBL method. ${ }^{15,16}$

One of the strongest arguments in favour of PBL is that it provides a more pleasant and stimulating learning environment for the students than LBL. This is similar to what Sankaran \& Bui has stated that the use of PBL method allows students to actively process information, thereby influencing their mastery of material and subsequent academic achievement. ${ }^{17}$ In the present study the students articulated that in comparison to LBL, PBL facilitates better learning abilities, deeper comprehension of the concepts and critical thinking in students. This result is congruent with the study of Chou, et al who reported that PBL enhance learning abilities, autonomy, and critical thinking in students. ${ }^{18}$ PBL can help learners develop broader perspectives of case scenarios in developing their curiosity and lifelong learning habits. The study results are in agreement with those of Claramita in which PBL was found to provoke the interest of medical students in participating in academic research related to anesthesia in their future professional careers. ${ }^{19}$ With regard to the attitude of students toward PBL, the present study indicated that students were highly motivated to learning in small groups. This finding is supported by the study findings of Schlett, et al, Maudsley, et al, and Tavakol, et al. ${ }^{20-22}$ Compare to LBL, PBL inflicts significant impact on how students find and use information. This is in consistent with the studies of Lorna Dodd et al. ${ }^{23}$ and Kuo-Inn Tsou, et al. ${ }^{24}$ Hwang in University of Illinois showed that PBL was more effective for improving students' knowledge and satisfactions than LBL, which is in conformity with the present study. $^{25}$

As per the results of this study PBL students develop better problem-solving skills, formulate evidence-based decisions and enhance their communication skills than LBL students. This is in conformity with the findings of Jungnickel, et al, Nii L, et al, Ross LA, et al and Strohfeldt K, et al. ${ }^{26-29}$ Increased retention of information, an integrated (rather than discipline bound) knowledge base, the development of lifelong learning skills, an exposure to real-life experience at an earlier stage in the curriculum, increased student-faculty interactions, and an increase in overall motivation are some of the benefits that have been previously identified. ${ }^{30-32}$ In PBL the selfstudy and group discussions develop skills, including self-directed learning, interdisciplinary knowledge creation and collaborative skills. The entire process is very interactive, achieving the goal of student engagement in learning, which has been shown to improve retention and satisfaction. ${ }^{33}$ In conformity with the findings of the study, Shahabudin demonstrated that PBL students showed better factual recall than traditionally educated students. ${ }^{34}$ Interestingly, Kaufman, et al reported that PBL students scored higher on the
National Board of Medical Examiners part 2 clinical science examination. ${ }^{35}$

The findings of the present study support the hypothesis that medical knowledge is certainly better retained if originally learned using PBL method compared with traditional lecture method. Hwang and Kim found that the level of knowledge in the PBL group was significantly higher than that of students in the lecture group. The results of the present study are in agreement with those of Hwang and Kim. ${ }^{36}$ McParland Monica, et al reported that a PBL curriculum resulted in significantly better examination performance than did the traditional teaching curriculum. ${ }^{37}$

However, the findings of the present study are in contrast to certain studies that reported that undergraduate students in a PBL group had lower knowledge acquisition compared with those who received the lecture method. ${ }^{38-40}$ Overall the findings of this study shows a definite advantage of problem based learning when compared to lecture based learning in equipping the learner with factual recall, analytical and critical thinking skills in addition to problem solving skills. The active participation of the students in case discussions, their independent and collective thinking related to practical scenarios, the triggers by different individuals in the group, discussion with the facilitator during the consolidation phase have been the major factors for superior scores obtained in the problem based learning method.

\section{CONCLUSIONS}

PBL has been found to be a more effective form of learning method with a greater degree of learning satisfaction and motivation as compared to the conventional LBL method. PBL method is a more effective instructional tool to foster critical thinking and problem solving skills among medical students as compared to the traditional LBL method. The study compared learning outcomes of recall, analysis and application when the OBG topics were taught using PBL and conventional LBL methods. The results of the study prove that in comparison to LBL, PBL method produces better outcomes of recall, analysis and application amongst the learners.

Implications of the study were, since the Medical Council of India is aiming for a curriculum focusing on competency based medical education, the teaching schedule of Indian Medical graduates has to change to incorporate more of problem based learning. PBL facilitates deeper learning in a non-intimidating environment and LBL is geared more towards acquiring a broader knowledge base. Therefore PBL and LBL could co-exist and enhance the learning experience. The Medical Council of India encourages integrated teaching using the PBL approach and it is encouraging to know 
that PBL has ventured into several well-known medical colleges as a choice over LBL method.

Limitations of the study were the small sample size used for the study and it is one of the major limitations for generalizing the findings to a wider perspective. The insufficient training received by the students in PBL and the time constraints were other important limitations of this study.

\section{Future research}

It is possible that a particular teaching method varies in effectiveness based on the aptitude of the tested students, and this would be an interesting area for further study. So further research can be conducted to compare the efficacy of PBL versus traditional LBL methods to assess whether PBL is more or less effective in improving the test scores of higher aptitude students.

In addition to demographic considerations, the quality and competence of the lecturer may play a role in test results. Learning in a traditional environment is dependent on the interaction between the lecturer and the students. PBL emphasizes a more social constructivist model and therefore a single factor such as the lecturer cannot be isolated in the same way. Therefore, future researchers may wish to study whether PBL is more or less effective versus a number of different lecturers.

Funding: No funding sources Conflict of interest: None declared

Ethical approval: The study was approved by the Institutional Ethics Committee

\section{REFERENCES}

1. Sungur S, Tekkaya C. Effects of problem-based learning and traditional instruction on self-regulated learning. J Edu Res. 2006;99(5):307-17.

2. Davis BG. Tools for teaching. San Francisco (CA): Jossey- Bass Publishers. 1993.

3. Dunnington G, Witzke D, Rubeck R, Beck A, Mohr J, Putnam C. A comparison of the teaching effectiveness of the didactic lecture and the problemoriented small group session: a prospective study. Surgery. 1987;102:291-6.

4. Savery JR, Duffy TM. Problem based learning: an instructional model and its constructivist framework. In B. Wilson (Ed.), Constructivist Learning Environments: Case Studies in Instructional Design. Englewood Cliff, NJ: Educational Technology Publications. 1996:135-148.

5. Barrows HS. Problem based learning in medicine and beyond: A brief overview. New Directions for Teaching \& Learning. 1996;68:3-12.

6. Spencer J, Jordan RL. Learner centered approaches in medical education. BMJ. 1999;123:534-6.
7. Banu A, Khan KA, Janani R. Problem based learning in Medical education- A review. J Edu Res Med. Teacher. 2014;2(2):1-5.

8. Becker KH, Maunsaiyat S. A comparison of students' achievement and attitudes between constructivist and traditional classroom environments in Thailand vocational electronics programs. J Vocat Edu Res. 2004;29(2):133-53.

9. Blumberg P. Evaluating the evidence that problembased learners are self-directed learners: A review of the literature. In D.H. Evensen \& E.E. Hmelo (Eds.), Problem-based learning: A research perspective on learning interactions. Mahwah, NJ: Erlbaum. 2000:199-226.

10. Chen SK, Chang HF, Chiang CP. Group learning factors in a problem based course in oral radiology. Dento Maxillo Facial Radiology. 2001;30(2):84-7.

11. Barrows HS, Tamlyn RM. Problem-based learning: Rationale and definition. In: Problem based learning: an approach to medical education. 1st Edition New York: Springer Publishing Company. 1980:1-18.

12. Koh GCH, Khoo HE, Koh D. The effects of problem-based learning during medical school on physician competency: a systematic review. CMAJ. 2008;178(1):34-41.

13. Ansari MT, Rahman SA, Badgujar VB, Sami F, Abdullah MS. Problem Based Learning (PBL): A Novel and Effective Tool of Teaching and Learning. Indian J Pharm Edu Res. 2015;49(4):258-65.

14. Gibbon C. Problem based learning \& nursing. 2011. http://www.ljmu.ac.uk/lid/ltweb

15. Tseng HC, Chou FH, Wang HH, Ko HK, Jian SY, Weng WC. The effectiveness of problem-based learning and concept mapping among Taiwanese registered nursing students. Nurse Educ Today. 2010;31(8):41-6.

16. Williams B. Self-direction in a problem based learning program. Nurse Educ Today. 2004;24(4):277-85.

17. Sankaran SR, Bui T. Effect of Student Attitude to Course Format on Learning Performance: An Empirical Study in Web vs. Lecture Instruction. J Instruct Psych. 2000.

18. Chou FH, Chin CC. Experience of problem-based learning in nursing education at Kaohsiung Medical University. Kaohsiung J Med Sci. 2009;25(5):25863.

19. Claramita M, Budiharjo S, Suryadi E. Profile of the integrated clinical skills competencies (ICSC) on students with and without problem-based learning exposure. 2nd Asia-Pacific Conference on ProblemBased Learning in Health Science. 2001;FP 25.

20. Schlett CL, Doll H, Dahmen J, Polacsek O, Federkeil G, Fischer MR. Job requirements compared to medical school education: differences between graduates from problem-based learning and conventional curricula. BMC Med Edu. 2010;10:1.

21. Maudsley G, Williams EM, Taylor DC. Problembased learning at the receiving end: A 'mixed methods' study of junior medical students' 
perspectives. Adv Health Sci Educ Theory Pract. 2008;13:435-51.

22. Tavakol M, Dennick R, Tavakol S. A descriptive study of medical educators' views of problem-based learning. BMC Med Educ. 2009;9:66.

23. Dodd L. The impact of problem-based learning on the information behavior and literacy of veterinary medicine students at university college Dublin. J Acad Librarianship. 2007;33:206-16.

24. Tsou KI, Cho SL, Lin CS, Sy LB, yang LK, Chan TY, et al. Short-term outcomes of a near-full PBL curriculum in a new Taiwan medical school. Kaohsiung J Med Sci. 2009;25:282-93.

25. Hwang SY, Kim MJ. A comparison of problembased learning and lecture-based learning in an adult health nursing course. Nurse Education Today. 2006;26:315-21.

26. Jungnickel PW, Kelley KW, Hammer DP, Haines ST, Marlowe KF. Addressing competencies for the future in the professional curriculum. American J Pharm Edu. 2009;73(8).

27. Nii LJ, Chin A. Comparative trial of problem based learning versus didactic lectures on clerkship performance. Am J Pharm Educ. 1996;60(2):162-4.

28. Ross LA, Crabtree BL, Theilman GD, Ross BS, Cleary JD, Byrd HJ. Implementation and refinement of a problem-based learning model: a ten-year experience. Am J Pharm Edu. 2007;71:1.

29. Strohfeldt K, Grant DT. A model for self-directed problem-based learning for renal therapeutics. Am J Pharm Educ. 2010;74(9):173.
30. Burch K. A primer on problem-based learning for international relations courses. Int Stud Perspect. 2000;1:31-44.

31. Dolmans D, Schmidt H. The advantages of problembased curricula. Post grad Med J. 1996;72:535-38.

32. Greening T. Scaffolding for success in problem based learning. Med Educ. 1998;3:1-15.

33. Berry W. Surviving lecture: a pedagogical alternative. College Teach. 2008;56:102-6.

34. Shahabudin SH. Content coverage in problem based learning. Med Educ.198;21:310-14.

35. Kaufman A, Mennin S, Waterman R, Duban S, Hansbarger C, Silverblatt H. The New Mexico experiment: educational innovation and institutional change. Acad Med. 1989;64:285.

36. Hwang SY, Kim MJ. A comparison of problembased learning and lecture-based learning in an adult health nursing course. Nurse Educ Today. 2006;26:315-21.

37. McParland M, Noble LM, Livingston G. The effectiveness of problem based learning compared to traditional teaching in undergraduate psychiatry. Med Educ. 2004;38:859-67.

38. Andrew M, Jones PR. Problem-based learning in an undergraduate nursing programme: a case study. J Adv Nurs. 1996;23:357-65.

39. Frost M. An analysis of the scope and value of problem based learning in the education of health care professionals. J Adv Nursing. 1996;24:1047-53.

40. Kim SA, Kang IA, Kim S, Nam KA, Park JH. Development of a problem-based learning program in nursing education curriculum. J Korean Psych Nursing. 2000;9:559-70.

Cite this article as: Augusthy VC. A comparative study of the learning outcomes and students' satisfaction from problem-based learning and lecturebased learning in obstetrics and gynaecology. Int J Reprod Contracept Obstet Gynecol 2016;5:1368-74. 